\title{
MARJA KALLASMAA 70
}

\author{
DOI: https://doi.org/10.12697/jeful.2020.11.1.01b
}

On 21 August 2020 Marja Kallasmaa, the senior lexicographer of the Institute of the Estonian Language and onomastician turns 70. This year is a symbolic milestone also for the reason that Marja Kallasmaa has worked at the Institute of the Estonian Language (previously the Institute of Language and Literature) for 45 years. This period of time full of consistent active work and total commitment has made Marja Kallasmaa the authority of Estonian onomastics. She has written three monographs (one of them in two volumes), participated in the compilation, editing or writing of another five books, and published more than a hundred articles.

Marja Kallasmaa was born and raised in Kehra, but her mother's Hiiumaa origin has had a great impact on her as well. Marja graduated from Kehra Secondary School in 1969 and entered Tartu State University specialising in Estonian language and literature. Following Professor Paul Ariste's recommendation, Marja headed towards the path of toponymics research with Valdek Pall as the supervisor. She graduated in 1975, her diploma thesis was on Tõstamaa place names. Subsequently, Marja was appointed to work at the Institute of Language and Literature, where she started as a laboratory assistant, then became a research student and in 1978 a junior research fellow. Marja defended her dissertation "The Structure of Estonian Microtoponymics (In the Context of the Western Dialect Subject Matter)" in 1981. At the same time, Marja's task at the institute was the compilation of "Dialectological Dictionary of Estonian" (part I in 1982, part II in 1989). Extensive examination of language databases and dialect vocabulary in the course of compiling the dictionary was of benefit in later research on names.

Marja Kallasmaa began more in-depth name research with the place names in Saaremaa. Part I of "The Place Names of Saaremaa" was published in 1996, part II in 2000. Saaremaa monograph constitutes a dictionary of toponyms (I) and a systematic approach (II), being a sequel to the regional research on Estonian toponyms started by Valdek 
Pall. The compilation of the first book took a dozen years and during that time, Marja Kallasmaa became a research fellow (1986) and then a senior research fellow (1994). On the basis of "The Place Names of Saaremaa", Marja defended her doctoral thesis at the University of Tartu in 2000 .

Marja's next interest was Hiiumaa and in 2010, her monogprah "The Place Names of Hiiumaa" saw the light of day. Meanwhile, a book "Names of Natural and Cultivation Objects in the Western Estonian Dialect" compiled on the basis of the materials of her doctoral thesis was published (2003).

Marja has put most of her work and knowledge of several decades into more than a thousand pages of "Dictionary of Estonian Toponyms" (2016, on the internet 2018). This masterpiece required more than seven years of work and was completed as a result of the cooperation project of many onomasticians. There are 16 authors in total and two editors: Peeter Päll and Marja Kallasmaa. However, it is more than likely that this book could not have come into being without Marja Kallasmaa. Marja has compiled more than three thousand name articles, i.e. a half of all name articles of the "Dictionary of Estonian Toponyms".

After the dictionary of toponyms was published, the working group of onomasticians began the compilation of another compelling work of Estonian names - "The Dictionary of Estonian Surnames" - and Marja's contribution is remarkable also in this work. The book will be completed in a couple of years.

Marja Kallasmaa as a valued expert participates in the work of the Place Names Board of Estonia and the Names Committee at the Tallinn City Government, she is also a member of the Mother Tongue Society and was a member of the International Council of Onomastic Sciences for a long time.

Marja Kallasmaa's main research area has been regional place name systems, she has raised many hypotheses on the origin of toponyms and thoroughly analysed different place name clusters of Estonia. Marja has emphasized that in the traditional etymologizing onomastics, researchers have tended to focus on rare and etymologically opaque names and the unravelling of specific individual cases has been a priority. In fact, we are surrounded primarily by etymologically transparent compound name types formed by simple means. Thus, in order to have a comprehensive view, these most widespread and common names should not be 
excluded and the whole place name cluster should be regarded together for finding solutions of a broader platform.

In addition, Marja Kallasmaa has written on subjects such as the problems of defining a name, relations between dialects and toponyms, names ending with -vere, microtoponyms, name borrowings, (ancient) personal names in place names, links between surnames and place names, history of Estonian onomastics, place name planning, etc. In her articles, Marja has repeatedly highlighted the fact that folk etymology has played a great role in the development of place names, probably greater than previously estimated. She has also emphasized that synchronic and diachronic research methods complement each other and encouraged to strive towards looking at the broader picture. Marja was also the first to employ the concept of density of toponymic collection in onomastics. Density of toponymic collection has become an important yardstick in regional research of place names for onomasticians toponymic collections can be measured and compared by this tool. As mentioned above, she has paid attention also to personal names besides place names, primarily to their connections with place names.

Marja has presented the results of her work in numerous international conferences and popularised these in Estonian public - these constitute an especially valuable basis for the researchers of the development and identities of Estonian locations. As a dedicated onomastician, Marja Kallasmaa has also taken care of the new generation of name researchers: one doctoral thesis and three Master's theses have been defended under her supervision.

Marja Kallasmaa has received the Ferdinand Johann Wiedemann language prize (2017) and twice the annual prize of the journal Keel ja Kirjandus ('Language and Literature') $(1992,1995)$ for her work.

We wish Marja continuous enthusiasm in research and pleasure in work also in the future!

On behalf of the colleagues

Tiina Laansalu and Peeter Päll 